\title{
Portrayal Of Holocaust Andalienation In The Light Of Trauma In Elie Wiesel's \\ Trilogynight, Day, Dawn
}

ANCY THRESIA N K

FACULTY OF ENGLISH

SHINE COLLEGE, ANTHIYOORKONAM

KERALA

\begin{abstract}
The Holocaust was the systematic, bureaucratic, state-sponsored persecution and murder of six million Jews by the Nazi regime and its collaborators. Holocaust is a word of Greek origin meaning "sacrifice by fire."All the books of Elie Wiesel deal with his struggle to handle the holocaust and to find God after the horror. As a survivor of holocaust Wiesel describes his own experiences, but words are not enough to explain his struggles. His books give us a clear picture of concentration camps and brutality of alienation created by Nazis.He is an AmericanRomanian Jewish writer who always raised his voice for the voiceless Jews.Night is the first book in the trilogy- Night, Dawn and Day which reflects Wiesel's state of mind during and after holocaust.
\end{abstract}

KEY WORDS: Holocaust, alienation, trauma, pain of separation, Elie Wiesel

The Holocaust was the systematic, bureaucratic, state-sponsored persecution and murder of six million Jews by the Nazi regime and its collaborators. Holocaust is a word of Greek origin meaning "sacrifice by fire."Post 1945 literature witnessed a gradual emergence of novel genres, writers and a variety of experimental topics. The war was the context for this abrupt change and 


\section{Thematics Journal of Geography}

it was then that the new genre of holocaust literature gained prominence. This new genre portrayed the effects, experiences and horror of people connected to the huge, incomprehensible and systematic mass murder in the history of mankind-THE HOLOCAUST. The Nazis used the phrase "final solution to the Jewish question" and the formula "final solution" has been widely used a term for the genocide of the Jews.

Many of the writers felt compelled to write these stories as away to immortalize those who were silenced by the Nazis. Their works were not mere words but were the burning memories through the dark days which returned only famished bodies and fractured minds to them. These writers acceded to share those painful memories with the hope that such adark age would never be repeated. In 1912, Adolf Hitler described propaganda as "a terrible weapon in the hands of an expert". Nazi propagandists employed the most modern communication technology of the time -radio, film, and even the television to spread their radical ideas. Today Islamic State of Iraq and Syria draws upon many of these same sophisticated techniques to win adherents around the world. And like the Nazi regime, it understands that terror too can be an effective form of propaganda.

The major themes that found in the Holocaust writings are holocaust, alienation, death, isolation, childhood memories, optimism, and loss of religious faith, dehumanization, friendship and brutality of war. All the books of Elie Wiesel deal with his struggle to handle the holocaust and to find God after the horror. As a survivor of holocaust Wiesel describes his own experiences, but words are not enough to explain his struggles. His books give us a clear picture of concentration camps and brutality of alienation created by Nazis. Wiesel is a victim of holocaust and in his each successive work readers can see the power of faith and religion. 


\section{Thematics Journal of Geography}

Almost all his works reflects Wiesel's state of mind during and after holocaust. He is an American- Romanian Jewish writer who always raised his voice for the voiceless Jews.

Night is the first book in the trilogy- Night, Dawn and Day which reflects Wiesel's state of mind during and after holocaust.Night touches the heart of the reader many a times when it narrates how the perspectives of men are completely changed under the circumstances of no bread, no water and little air. It strongly describes the relationship between father and son who at last reverse their relationship when the son becomes a father to his devastated father in a place where each one "lives and dies alone"

Dawn, the second novel in the trilogy was published in 1961.the novel tells the story of Elisha, a boy of 18, who just like the author, lost everything including his parents in the concentration camps. Now, a member of a Jewish terrorist group, he is assigned to kill a British man of his own father's age, but finds it difficult to do the execution since he finds no reason to hate the man. Elisha at last kills the man and Elisha's name is the last word on the dead man's lips. When the darkness falls away, everything has changed, it is dawn. Darkness always carries a face, a face of death, and Elisha realizes that it is his own face.

Day, the third book in the trilogy, was published in the UK as The Accident. Like the two former stories, Day is also a story about a holocaust survivor, the protagonist without a name, struggling to adjust with the life after the war. He is a journalist who finds it impossible to find any satisfaction in life. He is unexpectedly hit by a Taxi cab in New York City. He is badly injured. This sets off a series of memories in the protagonist that lets the reader take a journey through the protagonist's psychological and emotional struggles. His own experiences with fear, persecution, and humiliation made him unable to comprehend the more humane and 


\section{Thematics Journal of Geography}

beautiful aspects of humanity. He is injured emotionally and psychologically by the brutality of holocaust. It turns out the accident was actually a suicide attempt.

Hitler's "final solution" was a terrible time for our planet. Many innocent people were murdered in concentration camps. Families were separated and isolated and people were alienated from society. Elie Wiesel was also faced many brutalities of holocaust and through his works he clearly depict all these horrible experiences. Alienation happened in different ways as a group, from his family and within himself. Separating the Jewish people from the rest of the world, It demoralizes them and makes them fell less important. All the ill effects of holocaust and alienation are clearly depicted in his works without losing its essence.Meticulously planned and executed by Nazi Germany implementing the verdict of "the coarsest, cruellest, least magnanimous conqueror the world has ever known", the Holocaust saw the extermination of 6 million Jews. The term holocaust comes from the Greek adjective holokaustos, referring to an animal sacrifice offered to a god in which the whole (holos) animal is completely burnt (kaustos).

During holocaust man is alienated from society, family and even from his own self. Because he lost his identity and lots of pain and suffering are there in the life of those who were in concentration camps. The pains of separation, isolation, despair, rejection of faith, atheism are the factors which lead the holocaust victims to trauma. The trauma is used to refer both negative events and produce distress and to the distress itself. The field of trauma studies in literary criticism gained significant attention in 1996 with the publication of Cathy Caruth'sUnclaimed Experience: Trauma Narrative and History. Trauma refers to the event not the reaction and should be reserved for major events that are psychologically overwhelming for an individual. Trauma theory acquired from destruction. One of the main problems with trauma theory is the 


\section{Thematics Journal of Geography}

danger of overgeneralization. Freud believed that all people begin their life with a trauma that is the separation from the mother. Trauma creates a speechless fright that divides or destroys identity.

Unfortunately, the instruments of horror and subjugation used by agents of holocaust continued to be used in other forms and by other agents in the present scenarioalso. Today man is man's greatest enemy. Modern man is going to this trauma and holocaust is born in the minds of individual and this leads to alienation. Because today, evil is present in the subconscious mind of even the toddler. Evil has no time and space, it is inherent and it will never die. Now man is inert to evil because man himself becomes a carrier of holocaust and paves fertile ground for the birth of variants of Hitler.

\section{REFERENCES}

\section{Primary source}

Wiesel, Elie,TheNight Trilogy., New York: Noonday, 1998.Print

\section{Secondary sources}

Caruth ,CathyUnclaimed Experience: Trauma Narrative and History.OUP, 1995. Print

Hilberg, Rawl. The Perpetrators, Victims, Bystanders: The Jewish Catastrophe,

1933-1945. India: Harper Collins, 1993.Print.

“Holocaust Fiction”. Research-in-Collections, N.p, n.d.Web.25 Nov 2018

<http://www.ushmm.org/research/-in-collections/.../holocaust-fiction>

Roth, John K. "Rethinking the Holocaust”Holocaust Literature.Ed John K. 
Roth. Vol.2. Pasadena, CA: Salem, 2008.436-441. Print.

Wiesel, Elie, TheNight Trilogy., New York: Noonday,1998.Print 